\title{
Medicinal Plants as Aphrodisiac Agents: A Current Status
}

\author{
Saurabh Nimesh ${ }^{1 *}$, Shubham², Vrish Dhwaj Ashwlayan ${ }^{3}$ and Pankaj Barman ${ }^{4}$ \\ ${ }^{1}$ Department of Pharmaceutical Technology, Meerut Institute of Engineering and Technology, Meerut, Uttar Pradesh, India \\ ${ }^{2}$ Senior Veterinary Field Manager; Vet Mankind Pharma Ltd., Haldwani Headquarter, Uttarakhand, India \\ ${ }^{3}$ Associate Professor; Department of Pharmaceutical Technology, Meerut Institute of Engineering and Technology, Meerut, Uttar Pradesh, \\ India \\ ${ }^{4}$ M. Pharm. (Pharmacology) Student; Department of Pharmaceutical Technology, Meerut Institute of Engineering and Technology, Meerut, \\ Uttar Pradesh, India
}

*Corresponding Author: Saurabh Nimesh, Department of Pharmaceutical Technology, Meerut Institute of Engineering and Technology, Meerut, Uttar Pradesh, India.

Received: May 21, 2019; Published: July 25, 2019

DOI: $10.31080 /$ ASPS.2019.03.0355

\begin{abstract}
Modern life vogue and bound environmental exposures have resulted in male infertility. The activating factors turn out differing types of derangements that directly or indirectly cause sexual dysfunctions. Male impotence conjointly known as erectile dysfunction (ED) may be a common medical condition that affects the sexual lifetime of ample men worldwide. ED is outlined because the inability of a person to realize and maintain an erection adequate for naturally satisfactory intercourse. This literary criticism discusses regarding aphrodisiac potential of plants, its biological science name, Common name, family, parts used and chemical constituents, that are useful for investigator to development new aphrodisiac formulations. Hence, patients are seeking complementary and practice of medicine to treat sexual dysfunction. Ayurveda and different Indian literature mention the utilization of plants in numerous human ailments. India has regarding over 45000 plant species and among them many thousand are claimed to possess medicative properties.
\end{abstract}

Keywords: Sildenafil; Ayurveda; India; chemistry; Aphrodite; Fabaceae

\section{Abbreviations}

WHO: World Health Organization; ED: Erectile Dysfunction; NO: Nitric Oxide; ML: Mount Latency; IL: Intromission Latency; EL: Ejaculation Latency; MF: Mounting Frequency; IF: Intromission Frequency; PEI: Post-Ejaculatory Interval; Pgs: Phosphodiesterase; FSH: Follicle Stimulating Hormone

\section{Introduction}

Aphrodisiac is that the word derived from Aphrodite, the Greek god of sexual, love and sweetness. Associate aphrodisiac is outlined as an agent (food or drug) that arouses physical attraction or sexual desire [1]. The chance of bioactive aphrodisiacs which can be derived from plants, animals or minerals, has been engaging throughout recorded history [2]. Aphrodisiac are mentioned there as Vajikaranas, the word vaji that means horse and karanta meaning creating i.e. Live to excite lust by charms etc. Natural products are on the market in texts of Ayurveda for their spermatogenic and virility potential activities. Ayurvedic aphrodisiac medical specialty is classified into vajikarana (pharmacological) and rasayana (non-pharmacological products) [3]. The plant-based, ancient or traditional medicine systems still play an important role in health care, with regarding $80 \%$ of the world's inhabitants relying in the main on ancient medicines for his or her primary health care. Modern pharmacopoeia still contains a minimum of 25\% drugs derived from plants and plenty of others, that are artificial or synthetic analogues, designed on model compounds isolated from plants. Medicinal herbal plants produce bioactive compounds used in the main for medicinal functions [4-6]. Some well-known herbal aphrodisiacs are genus Allium sativum, Alpinia galangal, Anacardium occidentale, Anacyclus pyrethrum, Butea frondosa, Caesalpinia benthamiana, Cannabis sativa, Chlorophylum borivilianum, Citrullus lanatus, Eurycoma longifolia, Ginkgo biloba, Hibiscus sabdariffa, etc. Sexual relationships are a some of the foremost necessary social and biological relationship in human life. According to World Health Organization (WHO) Sexual health is prime to the physical or emotional health and wellbeing of people, couples and families and to the social or economic development of communities and countries $[7,8]$. The National Institutes of Health Consensus Development Conference on Impotence (7 December 1992) has outlined, Male impotence conjointly known as ED may be a common medical 
condition that affects the sexual life of millions of men worldwide. Impotency or ED as the 'inability to realize and maintain a penial erection adequate for satisfactory sexual relationship' (Figure 1) [9]. ED is outlined because the persistent inability to get associated maintain an erection comfortable for naturally satisfactory intercourse. Male reproductive capability was found to be deficient in nearly $50 \%$ of infertile couples in step with a study carried by the WHO. Sexual disfunction may be a serious medical and social symptom that happens in $10-52 \%$ of men and $25-63 \%$ of women [10-12].

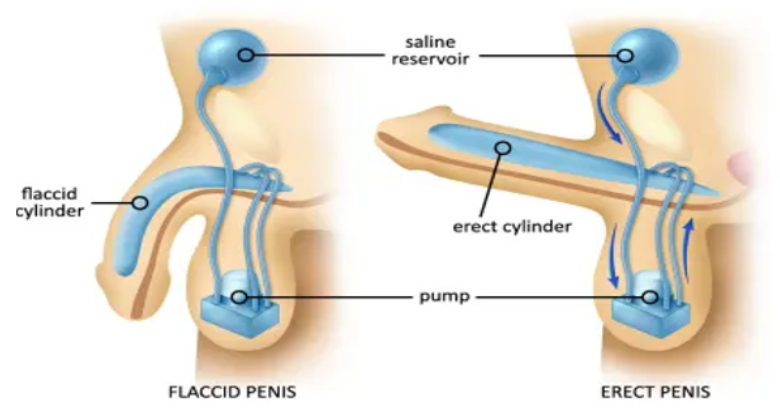

Figure 1: Spectrum of Erectile dysfunction.

Mechanism involved in aphrodisiac potentials (Table 1)

Sexual desire is controlled and regulated by the central nervous system that integrates tactile, olfactive and mental stimuli (Figure 2) [13].

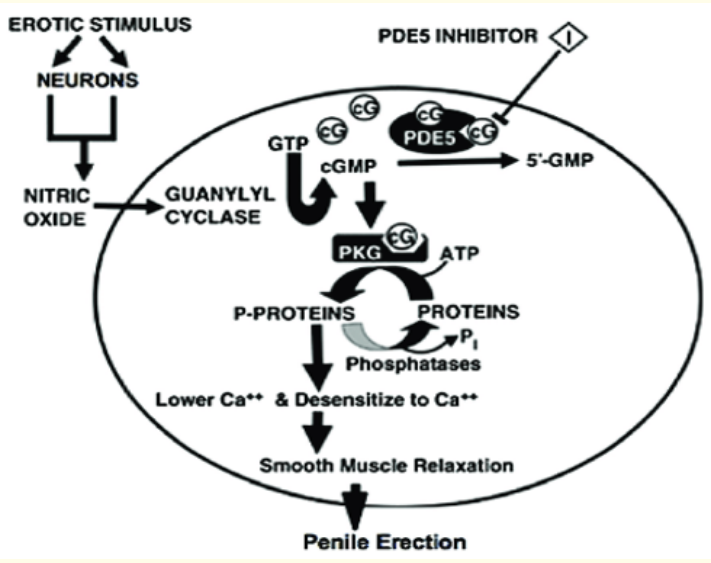

Figure 2: Mechanism of erection.

Side effects of Allopathic treatments used in sexual dysfunction

Side effects include drowsiness, insomnia, nasal congestion, headaches, dizziness, tachycardia, weight loss, etc. (Figure 3) [19].

\begin{tabular}{|l|l|l|}
\hline S. No. & Stages & \multicolumn{1}{c|}{ Explanation } \\
\hline 1 & First & $\begin{array}{l}\text { Some aphrodisiac merely provides a burst } \\
\text { of nutritionary worth rising the immediate } \\
\text { health or well-being of the patron and conse- } \\
\text { quently improving sexual performance and } \\
\text { concupiscence (libido). }\end{array}$ \\
\hline 2 & Second & $\begin{array}{l}\text { This cluster includes the supposed aphrodisiac } \\
\text { have a lot of specific physiological affects how- } \\
\text { ever don't seem to be psychologically active. } \\
\text { They will have an effect on blood flow; increase } \\
\text { duration of sexual intercourse by desensitizing } \\
\text { the sex organ space [14,15]. }\end{array}$ \\
\hline 3 & Third & $\begin{array}{l}\text { The third cluster of aphrodisiac is created up } \\
\text { compounds that are psychopharmacological, } \\
\text { i.e. they really cross the blood brain barriers } \\
\text { and stimulates some space of arousal [16]. } \\
\text { This class includes a wide range of neurotrans- } \\
\text { mitters, hormones, pheromones and drugs } \\
\text { that interfere with the traditional perform of } \\
\text { those molecules [17]. This class is most tough } \\
\text { to check as a result of information of each } \\
\text { arousal and therefore the mechanisms of the } \\
\text { psychoactive properties of drugs are restrict- } \\
\text { ed. Solely the foremost general data regarding } \\
\text { arousal and therefore the brain is known [18]. }\end{array}$ \\
\hline
\end{tabular}

Table 1

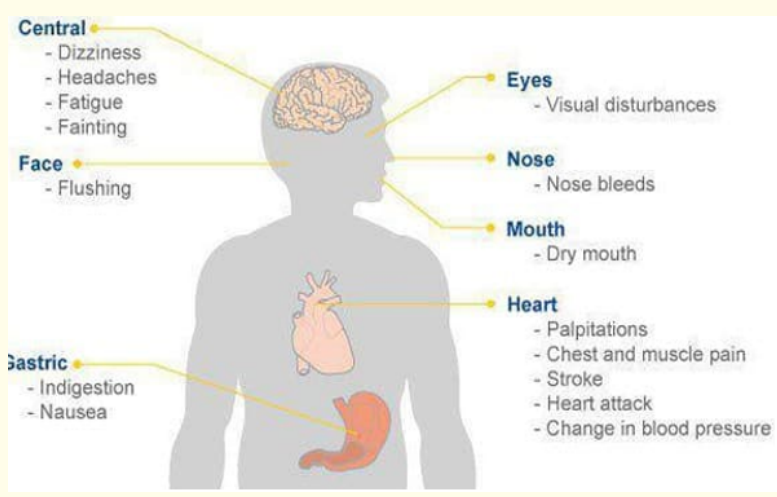

Figure 3: Side effects of sildenafil, avanafil, tadalafil and vardenafil.

Some medicinal plants with aphrodisiac potential

Some of the traditional plants have tested to possess a conventional similarly as scientifically proven aphrodisiac which will enhance passion, increase physical attraction, enhance sexual performance and facilitate to extend the intensity of sexual love [20]. A short report of aphrodisiac plants in table 2 [21-26]. 


\begin{tabular}{|c|c|c|c|c|c|}
\hline $\begin{array}{c}\text { Scientific name } \\
\text { (Family) }\end{array}$ & $\begin{array}{c}\text { Common } \\
\text { name }\end{array}$ & Pharmacology & Mechanism of action & Chemistry & $\begin{array}{l}\text { Class of } \\
\text { isolates }\end{array}$ \\
\hline $\begin{array}{l}\text { Allium sativum } \\
\text { (Amaryllida- } \\
\text { ceae) }\end{array}$ & Garlic & $\begin{array}{l}\text { The alcoholic extract of } A \text {. sa- } \\
\text { tium increased sexual behaviour } \\
\text { through the activities of sulphat- } \\
\text { ed compounds, peptides, flavo- } \\
\text { noids and phenolics }\end{array}$ & $\begin{array}{l}\text { Allicin increases blood flow to } \\
\text { sexual organs through nitric } \\
\text { oxide (NO) synthase }\end{array}$ & $\begin{array}{l}\text { Peptides, sulphated compounds, steroids, } \\
\text { flavonoids, volatile oils with sulphated } \\
\text { compounds like alliin, enzymes, minerals } \\
\text { and vitamins }\end{array}$ & $\begin{array}{l}\text { Peptides, } \\
\text { steroids, } \\
\text { terpenes, } \\
\text { flavonoids, } \\
\text { volatile oils } \\
\text { and vitamins }\end{array}$ \\
\hline $\begin{array}{l}\text { Alpinia galanga } \\
\text { (Zingiberaceae) }\end{array}$ & $\begin{array}{l}\text { Greater } \\
\text { galangal, } \\
\text { blue gin- } \\
\quad \text { ger }\end{array}$ & $\begin{array}{l}\text { Methanolic extract of } A \text {. galangal } \\
\text { showed increase in serum testos- } \\
\text { terone levels at } \\
300 \mathrm{mg} / \mathrm{kg} / \text { day }\end{array}$ & & $\begin{array}{l}\text { Spectroscopic analysis of sample has re- } \\
\text { vealed the presence of } 1 \text { 'S'-1'-acetoxychav- } \\
\text { icol acetate, } 1 \text { 'S'-1'acetoxyeugenol acetate, } \\
1 \text { 'S'-1' hydroxychavicol acetate, trans-p- } \\
\text { hydroxycinnam-aldehyde, trans-p-cou- } \\
\text { maryl alcohol, trans-p hydroxycinnamyl } \\
\text { acetate, } \beta \text { - bisaboline and } \beta \text {-selinene }\end{array}$ & $\begin{array}{l}\text { Coumarin, } \\
\text { terpenoids, } \\
\text { flavonoids, } \\
\text { volatile oils, } \\
\text { and phenols }\end{array}$ \\
\hline $\begin{array}{l}\text { Anacardium } \\
\text { occidentale } \\
\text { (Anacardiaceae) }\end{array}$ & Cashew & $\begin{array}{l}\text { In a study to determine the aph- } \\
\text { rodisiac activity of the oils from } \\
\text { A. occidentale seeds and shell, } \\
\text { the result showed significant in- } \\
\text { crease in sexual parameters }\end{array}$ & & $\begin{array}{l}\text { 2-hydroxy-6-pentadecylbenzoic acid, the } \\
\text { ethanolic extract of the nuts of } A \text {. occiden- } \\
\text { tale contains phytochemicals such as phe- } \\
\text { nols, } \\
\text { carbohydrates, proteins and xanthopro- } \\
\text { teins as well as volatile oils, 2,6-dihy- } \\
\text { droxybenzoic acid from cashew apple, my- } \\
\text { risticin, kaempferol, rhamnetin, cyanidin, } \\
\text { peonidin, delphinidin which are flavonoid } \\
\text { compounds. Other isolated compounds } \\
\text { are 2- hydroxy-6-pentadecylbenzoic acid, } \\
\text { cardinal and salicyclic acid }\end{array}$ & $\begin{array}{l}\text { Carbohy- } \\
\text { drates, } \\
\text { phenols, } \\
\text { flavonoids, } \\
\text { steroids, and } \\
\text { proteins }\end{array}$ \\
\hline $\begin{array}{l}\text { Anacyclus } \\
\text { pyrethrum } \\
\text { (Asteraceae) }\end{array}$ & Arkakara & $\begin{array}{l}\text { Administration of } 50 \mathrm{mg} / \mathrm{kg} \text { and } \\
100 \mathrm{mg} / \mathrm{kg} \text { of aqueous extract } \\
\text { in albino rats showed significant } \\
\text { anabolic and spermatogenic ef- } \\
\text { fects. In a separate study, petro- } \\
\text { leum ether extract had marked } \\
\text { influence on body weight and ac- } \\
\text { cessory sexual organs weight as } \\
\text { compared with arachis oil }\end{array}$ & $\begin{array}{l}\text { This could be partly explained } \\
\text { by its vasorelaxant properties } \\
\text { which may be caused by an in- } \\
\text { crease in NO } \\
\text { production in vascular bed and } \\
\text { a decrease in its destruction }\end{array}$ & $\begin{array}{l}\text { Alkyl amides, pyrethrins, inulin, sesamine, } \\
\text { hydrocaroline, pellitorine, volatile oils } \\
\text { such as it is also composed of } 2 \text {-phenyl } \\
\text { ethylamine, anacylin, } \beta \text {-biotol, salvia-4 } \\
(14) \text {-en-1-one. Eudesma-4(15),7- diene- } \\
\text { 1-ol and } \beta \text {-himachalol; the essential } \\
\text { oil also contains germacreme D, ger- } \\
\text { macreme-4(15),5,10(14) trien-1-a-ol, } \\
\text { caryophyllene oxide, cedryl acetate, eudes- } \\
\text { ma-4(15),7- diene- } 1-\beta \text {-ol and spathuleno }\end{array}$ & $\begin{array}{l}\text { Amides, and } \\
\text { Volatile oils }\end{array}$ \\
\hline $\begin{array}{l}\text { Butea frondosa } \\
\text { (Papilliona- } \\
\text { ceae) }\end{array}$ & $\begin{array}{l}\text { Flame of } \\
\text { the } \\
\text { forest, } \\
\text { bastard } \\
\text { teak }\end{array}$ & $\begin{array}{l}\text { The extract ( } 400 \mathrm{mg} / \mathrm{kg} \text { body } \\
\text { wt./day) was administered orally } \\
\text { by gavage for } 28 \text { days. } \\
\text { Mount latency (ML), intromis- } \\
\text { sion latency (IL), ejaculation la- } \\
\text { tency (EL), mounting frequency } \\
\text { (MF), intromission frequency } \\
\text { (IF), ejaculation frequency (EF) } \\
\text { and post-ejaculatory interval } \\
\text { (PEI) were the parameters ob- } \\
\text { served before and during the } \\
\text { sexual behaviour study at day } 0 \text {, } \\
7,10,14,21 \text {, and } 28 \text {. The extract } \\
\text { reduced significantly ML, IL, EL } \\
\text { and PEI (p < } 0.05 \text { ). The extract } \\
\text { also increased significantly MF, IF } \\
\text { and EF (p < } 0.05 \text { ). These effects } \\
\text { were observed in sexually active } \\
\text { and inactive male rats }\end{array}$ & & $\begin{array}{l}\text { Fixed oil } 18 \% \text {, Water soluble albuminoid } \\
\text { substances } 19 \% \text { and glucose } 6 \% \text {. Fatty ac- } \\
\text { ids isolated from this oil are orleic linoleic, } \\
\text { lenorlenic, palmitic, stearic, arachidic, } \\
\text { behenic and lingo cleric acid. Q-hydroxy- } \\
\text { 1-methyo allophonic acid, 15-hydroxy } \\
\text { pentasonic acid and 1carboxy methoxy- } \\
\text { 2-carboxy hydrazine have been isolated } \\
\text { from the seed coat. Seed has shown the } \\
\text { presence of alkaloid monspermine from } \\
\text { the alcoholic extract of the seeds are iden- } \\
\text { tified palasonin and palasonin-N-Phenyl } \\
\text { imidine. Aqueous methanolic extract } \\
\text { contains a triazine compound, 4-arbome- } \\
\text { thoxy-3-dioxo-hydro-1,2,4-triazine 4.Car- } \\
\text { boxymethoxy } 3.6 \text { dioxo-hydro 1, 2, 4, tri- } \\
\text { azine }\end{array}$ & $\begin{array}{l}\text { Amino acids, } \\
\text { alkaloids, and } \\
\text { fixed oils }\end{array}$ \\
\hline
\end{tabular}




\begin{tabular}{|c|c|c|c|c|c|}
\hline $\begin{array}{l}\text { Caesalpinia } \\
\text { benthamiana } \\
\text { (Caesalpini- } \\
\text { aceae) }\end{array}$ & Bail & $\begin{array}{l}\text { The methanolic extract exhibited } \\
\text { an accelerator effect by decreas- } \\
\text { ing the latent time. The oral ad- } \\
\text { ministration of aqueous extract } \\
\text { of } C \text {. benthamiana showed sig- } \\
\text { nificant increase in mounting } \\
\text { frequency and intromission fre- } \\
\text { quency the dosage of } 50 \mathrm{mg} / \mathrm{kg}\end{array}$ & & $\begin{array}{l}\text { The petroleum ether extract of the bark } \\
\text { has yielded cassane diterpenes with } \\
\text { antibacterial activity such as deoxycae- } \\
\text { saldekarine C, benthaminine I and ben- } \\
\text { thaminine 2, the aqueous extract contains } \\
\text { flavoinoids, phenols, anthraquinones such } \\
\text { as gallic acid, esveratrol; the chloroform } \\
\text { and n-butanol extract contains methyl gal- } \\
\text { late, shikimic acid-3-O-gallate, 1-O-meth- } \\
\text { yl-D-chiroinositol, (-)-epicatechin }\end{array}$ & $\begin{array}{l}\text { Terpenes, } \\
\text { benthamine, } \\
\text { fatty acids, } \\
\text { flavonoids, } \\
\text { and alkaloids }\end{array}$ \\
\hline $\begin{array}{l}\text { Cannabis sativa } \\
\text { (Cannabina- } \\
\text { ceae) }\end{array}$ & $\begin{array}{c}\text { Marijuana, } \\
\text { bhaang }\end{array}$ & $\begin{array}{l}\text { In India's Ayurveda and } \\
\text { Chinese, Unani medicine, canna- } \\
\text { bis used to overcome impotence } \\
\text { and raise libido and as a general } \\
\text { cure for the disease }\end{array}$ & & $\begin{array}{l}\text { Narcortic resin, cannabidiol, cannabidiol- } \\
\text { carboxylic acid, cannabigerol and can- } \\
\text { nabichromene, cannabipinol and canna- } \\
\text { bidivarin, phloroglucinol } \beta \text {-D-glucoside, } \\
\text { tetrahyrocannabinol, }\end{array}$ & $\begin{array}{l}\text { Cannabi- } \\
\text { noids, } \\
\text { Phenol, } \\
\text { alkaloid, fla- } \\
\text { vonoid, and } \\
\text { volatile } \\
\text { oils }\end{array}$ \\
\hline $\begin{array}{l}\text { Chlorophylum } \\
\text { borivilianum } \\
\text { (Asparagaceae) }\end{array}$ & $\begin{array}{l}\text { Safed } \\
\text { Musli }\end{array}$ & $\begin{array}{l}\text { In a study of the aqueous extract } \\
\text { of dried roots of } \\
\text { C. borivilianum in rats, there was } \\
\text { increase in libido, sexual vigour } \\
\text { and sexual arousal at } 250 \mathrm{mg} / \mathrm{kg} \text {. } \\
\text { The study supported treatment } \\
\text { of premature ejaculation and oli- } \\
\text { gospermia }\end{array}$ & $\begin{array}{l}\text { The chemical structure of stig- } \\
\text { masterol is related to that of } \\
\text { testosterone and mainly con- } \\
\text { tributes to its aphrodisiac po- } \\
\text { tentials; hecogenin produces } \\
\text { anabolic hormone }\end{array}$ & $\begin{array}{c}\text { Isolated compounds include stigmasterol } \\
\text { and hecogenin which are responsible } \\
\text { for its antioxidant power, anticancer and } \\
\text { aphrodisiac activities. Chlorophytoside-1, } \\
\text { fatty acids, eicosadienoic }\end{array}$ & $\begin{array}{l}\text { glycosides, } \\
\text { saponins, } \\
\text { fatty acids, } \\
\text { and hydro- } \\
\text { carbons }\end{array}$ \\
\hline $\begin{array}{l}\text { Citrullus lanatus } \\
\text { (Cucurbitaceae) }\end{array}$ & $\begin{array}{l}\text { Watermel- } \\
\text { on }\end{array}$ & $\begin{array}{l}\text { The effect of red watermelon } \\
\text { flesh extract on male sexual be- } \\
\text { haviour has been determined. } \\
\text { In the research, the suspension } \\
\text { of the flesh extract was admin- } \\
\text { istered on doses } 100,500 \text {, and } \\
1000 \mathrm{mg} / \mathrm{kg} \text { to different groups } \\
\text { of male rats (n=5) daily for } 22 \\
\text { days. The result showed that oral } \\
\text { administration of water melon } \\
\text { flesh extract caused significant } \\
\text { increase in mounting frequen- } \\
\text { cy, intromission frequency and } \\
\text { ejaculatory latency. Watermelon } \\
\text { flesh extract did not produce un- } \\
\text { desirable side effects on the male } \\
\text { rats and thus its short-term use is } \\
\text { apparently safe }\end{array}$ & $\begin{array}{l}\text { Citrulline improves blood drive } \\
\text { to the } \\
\text { genital regions and } \\
\text { plays a significant role in the } \\
\text { relaxation of blood, a major tool } \\
\text { in high sexual performance }\end{array}$ & $\begin{array}{c}\text { Watermelon contains bioactive agents } \\
\text { such as citrulline, } \beta \text {-carotene and lycopene } \\
\text { which have been used in the management } \\
\text { of prostate cancer }\end{array}$ & Carotenoids \\
\hline $\begin{array}{l}\text { Eurycoma } \\
\text { longifolia } \\
\text { (Simaro uba- } \\
\text { ceae) }\end{array}$ & $\begin{array}{l}\text { Tongkat } \\
\text { ali, pasak } \\
\text { bumi }\end{array}$ & $\begin{array}{l}\text { Standardized extract } \mathrm{F} 2 \text { at } 25 \\
\mathrm{mg} / \mathrm{kg} \text { and its quassinoids im- } \\
\text { proved rat spermatogenesis, im- } \\
\text { proved testosterone steroidgen- } \\
\text { esis. standardised water extract } \\
\text { at } 400 \mathrm{mg} / \text { day for six weeks on } \\
\text { testosterone, epitestosterone ra- } \\
\text { tio showed significant difference } \\
\text { between supplementation and } \\
\text { placebo. Treatment with } E \text {. longi- } \\
\text { folia extract at } 400 \mathrm{mg} / \text { day for } 5 \\
\text { weeks resulted to increase in free } \\
\text { and total testosterone concentra- } \\
\text { tion and muscular force in men } \\
\text { and women }\end{array}$ & $\begin{array}{l}\text { Improves spermatogenesis by } \\
\text { affecting the hypothalamic-pi- } \\
\text { tuitary-gonadal axis. Improves } \\
\text { testosterone by inhibiting aro- } \\
\text { matic conversion of testoster- } \\
\text { one to estrogen and may also } \\
\text { involve phosphodiesterase } \\
\text { (PGs) inhibition. The extracts } \\
\text { of } E \text {. longifolia affects male in- } \\
\text { fertility by suppressing } \alpha \text {-2HS } \\
\text { glycoprotein expression which } \\
\text { thereby increases testosterone } \\
\text { level and insulin sensitivity }\end{array}$ & 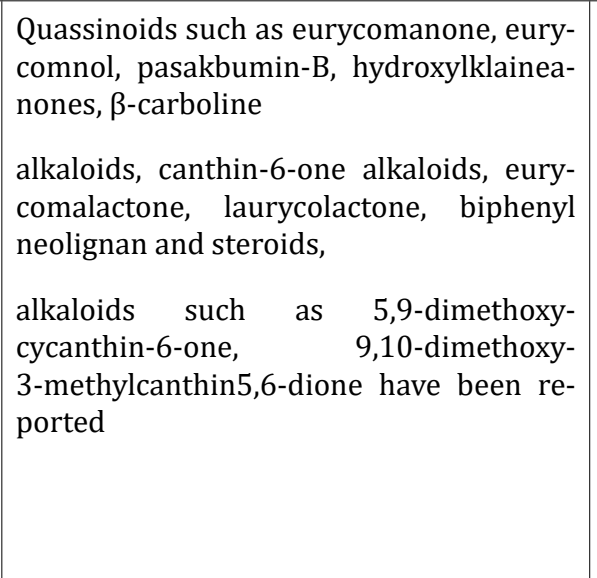 & $\begin{array}{l}\text { Phenols, } \\
\text { quassinoids, } \\
\text { alkaloids, } \\
\text { volatile } \\
\text { oils, and hy- } \\
\text { drocarbons }\end{array}$ \\
\hline
\end{tabular}




\begin{tabular}{|c|c|c|c|c|c|}
\hline $\begin{array}{l}\text { Ginkgo biloba } \\
\text { (Ginkgoaceae) }\end{array}$ & Gingko & $\begin{array}{l}\text { According to some researches, } \\
\text { extracts of G. biloba may also } \\
\text { help in psychological conditions } \\
\text { by easing stress, mild depres- } \\
\text { sion and anxiety- major causes of } \\
\text { poor sexual performance thereby } \\
\text { improving the mood for sexual } \\
\text { pleasure. G. biloba extract have } \\
\text { been used in traditional Chinese } \\
\text { medicine to improve blood circu- } \\
\text { lation. G. biloba constituents have } \\
\text { a thinning effect on the blood } \\
\text { besides helping to improve the } \\
\text { muscle tone in the walls of the } \\
\text { blood vessels }\end{array}$ & $\begin{array}{l}\text { Improved blood circulation } \\
\text { results to an increase in the } \\
\text { amount of oxygen in the blood } \\
\text { and to all major organs of the } \\
\text { body including the heart and } \\
\text { brain thereby resulting to an } \\
\text { increased arterial inflow to ar- } \\
\text { terial tissues through arteries } \\
\text { and veins without obstructing } \\
\text { systemic blood pressure. This } \\
\text { enhanced supply of blood to sex } \\
\text { organs is crucial in maintaining } \\
\text { strong erection }\end{array}$ & $\begin{array}{l}\text { GC-MS, HPLC-MS, HPLC-RI analysis of } \\
\text { samples have led to the characterization } \\
\text { of ginkgolides A, B, C, J, M with cage struc- } \\
\text { tures involving a tertiary butyl group and } \\
\text { six membered rings including a spironon- } \\
\text { ane system, a tetrahydrofuran and three } \\
\text { lactones groups. } 33 \text { flavonoids have been } \\
\text { isolated from the leaves including amento } \\
\text { flavone, quercetin, myricetin, sesquojafla- } \\
\text { vone, Ginkgetin, Isorhamnetin, etc. Gink- } \\
\text { golic acids have also been isolated; the } \\
\text { albumen of the seed also contains neuro- } \\
\text { toxic 4'-Omethylpyridoxine (ginkgotoxin), } \\
\text { etc }\end{array}$ & $\begin{array}{l}\text { Steroids, fla- } \\
\text { vonoid, and } \\
\text { ginkgosides }\end{array}$ \\
\hline $\begin{array}{l}\text { Hibiscus sabdar- } \\
\text { iffa } \\
\text { (Malvaceae) }\end{array}$ & Roselle & $\begin{array}{l}\text { Pharmacology of the testicular } \\
\text { effects of sub chronic admin- } \\
\text { istration of } H \text {. sabdariffa ca- } \\
\text { lyx aqueous extract in rats has } \\
\text { been determined. Doses of } 1.15 \text {, } \\
2.30 \text {, and } 4.60 \mathrm{~g} / \mathrm{kg} \text { for } 12 \text { weeks } \\
\text { showed in significant change in } \\
\text { the absolute and relative testicu- } \\
\text { lar weights; significant decrease } \\
\text { in the epididymal sperm } \\
\text { count and induced testicular tox- } \\
\text { icity }\end{array}$ & $\begin{array}{l}\text { It decreases the viscosity of the } \\
\text { blood and stimulates internal } \\
\text { peristalsis }\end{array}$ & $\begin{array}{l}\text { Several compounds have been isolated } \\
\text { from different parts of } H \text {. sabdariffa includ- } \\
\text { ing } \beta \text {-carotene, vitamin C, riboflavin, thia- } \\
\text { mine, and nutrients such as protein, car- } \\
\text { bohydrates and minerals like calcium and } \\
\text { iron. H. sabdariffa is composed chiefly of } \\
\text { organic acids, anthocyanins, polysaccha- } \\
\text { rides and flavonoids. Spectroscopic analy- } \\
\text { sis off the aqueous extract of } H \text {. sabdariffa } \\
\text { have yielded citric acids, hydroxycitric } \\
\text { acid, hibiscus acid, malic acid and tartaric } \\
\text { acids; oxalic acid as minor compounds. } \\
\text { Delphinidin and cyanidin based anthocya- } \\
\text { nins including delphinidin-3-saambubio- } \\
\text { side (Hibiscin), cyanidin- 3,5-diglucoside, } \\
\text { delphinidin, etc. have been reported }\end{array}$ & $\begin{array}{l}\text { Carotenoids, } \\
\text { vitamins, } \\
\text { flavonoids, } \\
\text { minerals, and } \\
\text { amino acids }\end{array}$ \\
\hline $\begin{array}{l}\text { Lepidium mey- } \\
\text { enii } \\
\text { (Cruciferae) }\end{array}$ & $\begin{array}{l}\text { Peruvian } \\
\text { ginseng, } \\
\text { maca }\end{array}$ & $\begin{array}{l}\text { In a research, treatment of rats } \\
\text { with maca at high altitudes pre- } \\
\text { vented high altitude spermato- } \\
\text { genic disruption. In a separate } \\
\text { study, } 1500 \mathrm{mg} / \mathrm{kg} \text { or } 3000 \mathrm{mg} / \\
\text { kg orally showed no significant } \\
\text { effect on serum levels of leutiniz- } \\
\text { ing and follicle stimulating hor- } \\
\text { mone (FSH) }\end{array}$ & $\begin{array}{l}\text { Maca improves stamina and } \\
\text { endurance, mood, and libido } \\
\text { and erectile capabilities due to } \\
\text { the presence of arginine which } \\
\text { boosts NO which relaxes blood } \\
\text { vessels, the same basic effect } \\
\text { Viagra produces }\end{array}$ & $\begin{array}{l}\text { Macamides such as benzylglucosinolate, } \\
\text { benzylisocyanate, benzyl nitrile, benzyl } \\
\text { alcohol, benzylaldehyde, benzylamine, } \\
\text { hexanal, linoleic acid, N-benzylhexadecan- } \\
\text { amide, alkaloids, fatty acids, amino acids }\end{array}$ & $\begin{array}{l}\text { Macamides, } \\
\text { alkaloids, } \\
\text { amino acids, } \\
\text { and fatty } \\
\text { acids }\end{array}$ \\
\hline $\begin{array}{l}\text { Mimosa tenui- } \\
\text { flora } \\
\text { (Fabaceae) }\end{array}$ & $\begin{array}{l}\text { Jurema } \\
\text { preta, } \\
\text { calumbi }\end{array}$ & $\begin{array}{l}\text { A research into the spermatic } \\
\text { characteristics of } M \text {. tenuiflora on } \\
\text { ram showed no significant differ- } \\
\text { ences (P }>0.05) \text { for the progres- } \\
\text { sive motility, spermatic strength } \\
\text { and morphology among the } \\
\text { sheep with or without } M \text {. tenui- } \\
\text { flora. The result indicated that } \\
M \text {. tenuiflora does not influence } \\
\text { negatively on spermatic charac- } \\
\text { teristics of the sheep }\end{array}$ & & $\begin{array}{l}\text { Two alkaloids have been isolated from } \\
M \text { tenuiflora and includes 5-hydroxy- } \\
\text { typtamine and N, N- dimethyltryptamine. } \\
M \text { tenuiflora is also composed of yure- } \\
\text { manine and two chalcones; kukulkan } \\
\text { A (2'.4',-dihyroxy-3'-4-dihydroxychal- } \\
\text { cone), kukulkan B (2',4',4- trihydroxy- } \\
\text { 3-methoxychalcone). } M \text { tenuiflora is also } \\
\text { composed of the steroidscampesterol-3- } \\
\text { 0- } \beta \text {-D-glucopyranosyl, stigmasterol-3- } \\
\text { O- } \beta \text {-D-glucopyranosyl and } \beta \text {-sitosterol- } \\
\text { 3-0- } \beta \text {-Dglucopyranosyl. Saponins such } \\
\text { as mimonoside A, mimonoside B, mi- } \\
\text { monoside C have been isolated. Five } \\
\text { 2-phenoxychromones ("uncommon" } \\
\text { flavonoids), the tenuiflorin A [5,7-di- } \\
\text { hydroxy-2-(3-hydroxy-4-methoxyphe- } \\
\text { noxy)-6 methoxychromone], tenuiflorin B } \\
\text { [5,7-dihydroxy-2-(4-hydroxy-3-methoxy- } \\
\text { phenoxy)- 6-methoxychromone] and } \\
\text { tenuiflorin C and 6-demethoxy-4'-0- } \\
\text { methylcapillarisin were isolated from the } \\
\text { leaves of M. tenuiflora }\end{array}$ & $\begin{array}{l}\text { Alkaloids, } \\
\text { steroids, and } \\
\text { flavonoids }\end{array}$ \\
\hline
\end{tabular}




\begin{tabular}{|c|c|c|c|c|c|}
\hline $\begin{array}{l}\text { Mucuna pru- } \\
\text { riens } \\
\text { (Fabaceae) }\end{array}$ & $\begin{array}{l}\text { Velvet } \\
\text { beans, } \\
\text { lyon bean }\end{array}$ & $\begin{array}{l}\text { In different texts of Ayurveda, } M . \\
\text { pruriens is } \\
\text { most commonly used in } \\
\text { aphrodisiac formulations. At } 70 \\
\text { mg/kg, treatments significantly } \\
\text { improved } \\
\text { testosterone quality, } \\
\text { ameliorated Psychological stress } \\
\text { and improved sperm count }\end{array}$ & $\begin{array}{l}\text { Producing a dose dependent } \\
\text { increase in FSH and leutenizing } \\
\text { hormone which increases the } \\
\text { number of eggs } \\
\text { released at ovulation by the ac- } \\
\text { tion of L-DOPA and dopamine }\end{array}$ & $\begin{array}{l}\text { L-DOPA, serotonin, mucunain, arachidic } \\
\text { acid, behenic acid, genistein, glutamic ac- } \\
\text { ids, betacarboline, } \beta \text {-sitosterol, cysteine, } \\
\text { dopamine, lysine, tryptamine, } \\
\text { riboflavin }\end{array}$ & $\begin{array}{l}\text { Alkaloids, } \\
\text { amino acids, } \\
\text { saponins, } \\
\text { and vitamins }\end{array}$ \\
\hline $\begin{array}{l}\text { Musa (Musa } \\
\text { paradisiacal/ } \\
\text { sapientum) } \\
\text { (Musaceae) }\end{array}$ & $\begin{array}{l}\text { Banana, } \\
\text { plantain }\end{array}$ & $\begin{array}{l}\text { Aqueous extract of } M \text {. paradi- } \\
\text { siaca root on testicular function } \\
\text { parameters on male rats at } 25 \text {, } \\
\qquad 50 \text { and } 100 \mathrm{mg} / \mathrm{kg} \\
\text { enhanced the testosterone } \\
\text { dependent normal functioning of } \\
\text { the testes. } M \text {. sapientum contain } \\
\text { bromine, norepinephrine, dopa- } \\
\text { mine and serotonin in the peel } \\
\text { and pulp. Norepinephrine and } \\
\text { dopamine elevate blood pres- } \\
\text { sure while serotonin stimulates } \\
\text { the blood vessels of the intestine }\end{array}$ & $\begin{array}{l}\text { Increase in blood } \\
\text { Circulation }\end{array}$ & $\begin{array}{l}\text { Bromine, rubidium, strontium, saponins, } \\
\text { norepinephrine, dopamine, serotonin, } \\
\text { vitamin } \mathrm{B}_{6} \text {, vitamin a, c and D and natural } \\
\text { glucose, fructose. Several compounds } \\
\text { such as acyl steryl glycoside such a sitoin- } \\
\text { doside-I, sitoindoside-II, sitoindoside-III, } \\
\text { sitoindoside-IV and steryl glycosides such } \\
\text { as sitosterol, myo-inosityl- } \beta \text {-D-glucoside } \\
\text { have been isolated from fruits of } M \text {. } \\
\text { paradisiaca, A bicyclic diarylheptanoid, } \\
\text { rel-(3S, 4aR,10bR)-8-hydroxy-3- }(4- \\
\text { hydroxyphenyl)-9-methoxy-4a,5,6,10b- } \\
\text { tetrahydro-3H-naphthol[2,1- } b] \text { pyran, } \\
\text { and 1,2-dihydro-1,2,3trihydroxy-9-(4- } \\
\text { hydroxyphenyl) naphthalic anhydride, } \\
\text { 1,7-bis (4-hydroxyphenyl) hepta-4(E), } \\
6(E) \text {-dien-3-one have also been isolated, } \\
\text { cyclomusalenol, cyclomusalenone }\end{array}$ & $\begin{array}{l}\text { Saponins, } \\
\text { alkaloids, } \\
\text { vitamins, } \\
\text { glycosides, } \\
\text { triterpenes, } \\
\text { and sterols }\end{array}$ \\
\hline $\begin{array}{l}\text { Myristica fra- } \\
\text { grans } \\
\text { (Myristiaceae) }\end{array}$ & $\begin{array}{l}\text { Nutmeg, } \\
\text { mace }\end{array}$ & $\begin{array}{l}50 \% \text { ethanolic extract showed } \\
\text { significant increase in aphrodi- } \\
\text { siac properties in mice such as } \\
\text { increase in mating frequency, } \\
\text { libido and potency. It has also } \\
\text { been } \\
\text { used in Unani medicine for the } \\
\text { treatment of sexual disorders }\end{array}$ & $\begin{array}{l}\text { Stimulation of the nervous } \\
\text { system by myristicin }\end{array}$ & $\begin{array}{c}\text { A-pinene, camphene, } \rho \text {-cymene, sabinene, } \\
\text { } \text { phillandiene, } \gamma \text {-terpinene, limonene, } \\
\text { myrcene, linalool, } 3 \text {-methyl-4-decan-1-ol, } \\
\text { fixed oils like mysristic, stearic, palmitic, } \\
\text { oleic and olenolic acids, Licarin B and } \\
\text { malabaricone C }\end{array}$ & $\begin{array}{l}\text { Essential oils, } \\
\text { fixed oils, and } \\
\text { unsaturated } \\
\text { aliphatic } \\
\text { hydrocarbon }\end{array}$ \\
\hline $\begin{array}{l}\text { Ocimum } \\
\text { gratissimum } \\
\text { (Lamiaceae) }\end{array}$ & $\begin{array}{l}\text { Ocimum, } \\
\text { wild basil }\end{array}$ & $\begin{array}{l}\text { Oral administration of extracts of } \\
\text { O. gratissimum at } 100,250 \text { and } \\
500 \mathrm{mg} / \mathrm{kg} \text { to } 6 \text { groups of male } \\
\text { rats once a day for seven days } \\
\text { showed significant increase in } \\
\text { mounting frequency, intromis- } \\
\text { sion frequency, erection and } \\
\text { aggregate penile reflexes }\end{array}$ & & $\begin{array}{c}\text { O. gratissimum consist of several essen- } \\
\text { tial oils such as thymol, eugenol, methyl } \\
\text { charvical, } \\
\text { gratissimol, pentoses, hexoses, uronic } \\
\text { acid, alkaloids, tannins, flavonoids, methyl } \\
\text { eugenol, cis-ocimene, trans-ocimene, } \\
\text { pinene, camphor, germacrene-D, trans- } \\
\text { carypophyllene, farnesene, l-bisaboline, } \\
\text { p-cymene, } \gamma \text {-terpene, } \alpha \text {-trans sabiene } \\
\text { hydrate, } 1,8 \text { - cineole, linalool, } \beta \text {-salinene, } \\
\text { and geraniol }\end{array}$ & $\begin{array}{l}\text { Volatile oils, } \\
\text { alkaloids, } \\
\text { and tannins }\end{array}$ \\
\hline $\begin{array}{l}\text { Panax ginseng } \\
\text { (Araliaceae) }\end{array}$ & $\begin{array}{l}\text { Ginseng } \\
\text { berry }\end{array}$ & $\begin{array}{l}\text { Panax extract standardized with } \\
\text { gensenoside Rg3 significantly } \\
\text { produced significant and sus- } \\
\text { tains increase in sexual activity } \\
\text { of normal male rats. Improve- } \\
\text { ment in all forms of sexual } \\
\text { dysfunction including erectile } \\
\text { dysfunction and premature } \\
\text { ejaculation }\end{array}$ & $\begin{array}{l}\text { Ginsenosides enhances acetyl- } \\
\text { choline-induced and transmu- } \\
\text { ral nerve stimulation-activated } \\
\text { relaxation associated } \\
\text { with increasing tissue cGMP } \\
\text { mediated by the release of NO }\end{array}$ & $\begin{array}{c}\text { Triterpene glycosides called ginsenosides. } \\
\text { Alkanes, alkenes, sterols, fatty acids, } \\
\text { carbohydrates, flavonoids, organic acids } \\
\text { and vitamin }\end{array}$ & $\begin{array}{l}\text { Saponins, hy- } \\
\text { drocarbons, } \\
\text { flavonoids } \\
\text { and vitamin }\end{array}$ \\
\hline
\end{tabular}




\begin{tabular}{|c|c|c|c|c|}
\hline $\begin{array}{l}\text { Passiflora incar- } \\
\text { nata (Passiflora- } \\
\text { ceae) }\end{array}$ & $\begin{array}{l}\text { Passionflo- } \\
\text { wer, wild } \\
\text { passion } \\
\text { vine }\end{array}$ & $\begin{array}{l}\text { The aphrodisiac effect of the } \\
\text { methanolic extract of } P \text {. incarnate } \\
\text { has been } \\
\text { determined in mice. The } \\
\text { result showed significant aphro- } \\
\text { disiac properties in } \\
\text { male mice at all doses- } 75,100 \\
\text { and } 150 \mathrm{mg} / \mathrm{kg} \text { with } 100 \mathrm{mg} / \mathrm{kg} \\
\text { having the highest activity }\end{array}$ & $\begin{array}{l}\text { Several compounds such as flavonoids and } \\
\text { other phenolics have been isolated from } P \text {. } \\
\text { incarnate such as apigenin and luteolin, } \\
\text { isovitexin, vitexin, isoorientin, orientin } \\
\text { and saponarin. Also isolated from } P \text {. incar- } \\
\text { nate includes schaftoside, } \\
\text { isoschaftoside, isovitexin-2'-0- } \beta \text {-glucoside } \\
\text { and isoorientin- } 2-0 \text { - } \beta \text {-glucoside }\end{array}$ & $\begin{array}{l}\text { Phenolics, } \\
\text { alkaloids, } \\
\text { and sugars }\end{array}$ \\
\hline
\end{tabular}

Table 2: Medicinal Plants used for the improvement of sexual performance and virility.

\section{Conclusion}

Herbals medicinal plants have a possible to treat the assorted varieties of body ailments. The demand of herbal medicine is increasing day by day in developed yet as developing countries as a result of they are safer and well tolerated as compared to those of allopathic drugs. These plants must be subjected to animal and human studies to figure out their effectiveness in whole organism systems. Many plants have tried helpful within the management of sexual disorders throughout history, even herbs and spices are accustomed increased sexual activities in varied components of the world. There's great would like for substances that are accustomed treat sexual dysfunction in humans. The utilization of aphrodisiacs is outstanding in several countries of the world as well as Asian country like India, China, Sri Lanka, and Pakistan.

\section{Acknowledgement}

The authors are thankful to the Mr. Jivan Kumar; Production officer of Kusum Healthcare Pvt. Ltd. Chopanki, Bhiwadi (Rajasthan) India, for her support and helpful in cooperation in the review and data collection process.

\section{Conflict of Interest}

The authors declare that there is no conflict of interest regarding the publication of this paper.

\section{Bibliography}

1. Jo JK., et al. "Effect of starting penile rehabilitation with sildenafil immediately after robot-assisted laparoscopic radical prostatectomy on erectile function recovery: A prospective randomized trial". Journal of Urology 199.6 (2018): 1600-1606.

2. Goethe VE., et al. "Concordance and discordance of sexual identity, sexual experience and current sexual behavior in 45-year old men: Results from the German Male Sex-Study". The Journal of Sexual Medicine 6.4 (2018): 282-290.

3. Lane-Cordova AD., et al. "Association between cardiovascular health and endothelial function with future erectile dysfunction: The Multi-Ethnic Study of Atherosclerosis". American Journal of Hypertension 30.8 (2017): 815-821.
4. Jisheng W., et al. "Comparison of TCM and western medicine diagnosis and treatment strategies for erectile dysfunction". Chinese Canadian Journal of Human Sexuality 26 (2017): 23-26.

5. Rongmin J., et al. "Meta-analysis of clinical effectiveness of the acupuncture treatment for erectile dysfunction". Chinese Canadian Journal of $\mathrm{Hu}$ man Sexuality 27 (2018): 82-85.

6. Kaminetsky JC., et al. "Quality of erections by age group in men with erectile dysfunction". International Journal of Clinical Practice 71.10 (2017):12976.

7. Wang X and Wang MLI. "Discussing on the action mechanism of two-way adjustment of acupuncture". Journal of Sichuan Traditional Chinese Medicine 35 (2017):40-42.

8. Onyeji IC., et al. "Impact of surgeon case volume on reoperation rates after inflatable penile prosthesis surgery". Journal of Urology 197.12 (2017): 223-229.

9. Cocci A., et al. "Predictive factors of patients and their partners sexual function improvement after collagenase clostridium histolyticum injection for Peyronie's disease: Results from a multi-center single-arm study". The Journal of Sexual Medicine 15.5 (2018): 716-721.

10. Ren H., et al. "Comparative effects of umbilical cord- and menstrual bloodderived MSCs in repairing acute lung injury". Stem Cells International (2018).

11. Wang J., et al. "The safety and efficacy of acupuncture for erectile dysfunction: A Network meta-analysis". Medicine 98.2 (2019): 1-4.

12. Burnett AL., et al. "Erectile dysfunction: AUA guideline". Journal of Urology 200.3 (2018): 633-641.

13. Pozzi E., et al. "Clinical profile of young patients with erectile dysfunction: Preliminary findings of a real-life cross-sectional study". European Urology Focus (2018).

14. Kalka D., et al. "564 Do socioeconomic factors influence the pathogenesis of erectile dysfunction through modifiable risk factors?". The Journal of Sexual Medicine 15.7 (2018): 335. 
15. Deng C., et al. "Treatment of human chronic wounds with autologous extracellular matrix/stromal vascular fraction gel: A STROBE compliant study". Medicine (Baltimore) 97.32 (2018).

16. Sarwer DB., et al. "4-Year changes in sex hormones, sexual functioning and psychosocial status in women who underwent bariatric surgery". Obesity Surgery 28.4 (2018):892-899.

17. Aversa A., et al. "Tadalafil improves lean mass and endothelial function in nonobese men with mild ED/LUTS: in vivo and in vitro characterization". Endocrine 56.3 (2017): 639-648.

18. Amano T., et al. "Administration of daily $5 \mathrm{mg}$ tadalafil improves endothelial function in patients with benign prostatic hyperplasia". Aging Male 21.1 (2018):77-82.

19. Mulhall JP., et al. "Predictors of erectile function normalization in men with erectile dysfunction treated with placebo". The Journal of Sexual Medicine 15.6 (2018): 866-872.

20. Lunsen RHW., et al. "Maintaining physiological testosterone levels by adding dehydroepiandrosterone to combined oral contraceptives: II. Effects on sexual function". Contraception 98.1 (2018): 56-62.

21. Ahlers CJ., et al. "How unusual are the contents of paraphilias? Paraphiliaassociated sexual arousal patterns in a community-based sample of men". The Journal of Sexual Medicine 8.5 (2011): 1362-1370.

22. McPhail IV. "Age of onset in pedohebephilic interests". Archives of Sexual Behavior 47.5 (2018): 1313-1317.

23. Tozdan S., et al. "Keep faith in yourself! -A pilot study on the relevance of specific self-efficacy for modifying sexual interest in children among men with a risk to sexually abuse children". Journal of Sex and Marital Therapy 6 (2018): 1-14

24. Corona G., et al. "EDEUS, a real-life study on the users of phosphodiesterase type 5 inhibitors: Prevalence, perceptions and health careseeking behavior among European men with a focus on 2nd-generation avanafil". Sexual Medicine 6.1 (2018): 15-23.

25. Hutchings DC., et al. "Phosphodiesterase-5 inhibitors and the heart: Compound cardioprotection?" Heart 104.15 (2018): 1244-1250.

26. Osondu CU., et al. "The relationship of erectile dysfunction and subclinical cardiovascular disease: A systematic review and meta-analysis”. Vascular Medicine 23.1 (2018): 9-20.

\section{Volume 3 Issue 8 August 2019}

(C) All rights are reserved by Saurabh Nimesh., et al. 